\title{
Parathyroid carcinoma presenting as tertiary hyperparathyroidism
}

\author{
D.J. Sherlock ${ }^{1^{*}}$, J. Newman ${ }^{2}$ and R.T.J. Holl-Allen ${ }^{1}$
}

Departments of ${ }^{1}$ Surgery and ${ }^{2}$ Pathology, East Birmingham Hospital, Bordesley Green East, Birmingham B9 5ST, $U K$.

\begin{abstract}
Summary: A case of malignant transformation in established secondary hyperparathyroidism presenting as tertiary hyperparathyroidism is reported. Although rare, this occurrence has important medical and surgical implications.
\end{abstract}

\section{Introduction}

A case of malignant transformation in established secondary hyperparathyroidism is reported; this presented as tertiary hyperparathyroidism and the histology is discussed. This case would appear to support the concept of malignant transformation occurring in benign parathyroid disease. Although rare, this predisposition has important implications, especially for borderline cases treated conservatively at present.

\section{Case report}

A 42 year old dialysis patient with increasing hypercalcaemia was referred for parathyroidectomy in early 1983. She had been on haemodialysis for 7 years with end-stage renal failure due to chronic glomerulonephritis. She was asymptomatic, but a routine skeletal survey in 1979 had shown marked renal oesteodystrophy, confirmed by bone biopsy.

Initially she had required supplements of calcium carbonate and $1-\alpha$ cholecalciferol to maintain eucalcaemia in early 1980 . However later in that year, this period of secondary hyperparathyroidism ended as the level rose above normal. During 1982, the serum calcium began to rise rapidly, reaching a maximum of $3.23 \mathrm{mmol} / \mathrm{l}$. At this time the parathyroid hormone level (PTH) was greater than $10 \mathrm{ng} / \mathrm{ml}$ (normal $<0.2 \mathrm{ng} / \mathrm{ml}$; C-terminal radio-immune assay).

D.J. Sherlock, F.R.C.S.; J. Newman, M.R.C.Path.; R.T.J. Holl-Allen, M.S. M.D., F.R.C.S.

Correspondence: R.T.J. Holl-Allen, East Birmingham Hospital, Birmingham B9 5ST.

* Present address: Department of Surgery, Dowstate Medical Center, Box 40, 450 Clarkson Avenue, Brooklyn, New York 11203, USA

Accepted: 7 March 1984
At operation a large hard $4.0 \mathrm{~cm} \times 2.0 \mathrm{~cm}$ gland was removed from the left upper pole adherent firmly to the thyroid gland. The other three glands were removed also, a portion of one being autotransplanted. Histological examination indicated that the large gland was carcinoma. The tumour invaded the capsule, thyroid gland and a few small veins (Figure 1). Focally it had a trabecular structure and showed cytological pleomorphism together with a number of mitoses. The remaining three glands displayed nodular hyperplasia.

The serum calcium fell rapidly post-operatively, requiring administration of intravenous calcium gluconate on several occasions. She remains well one year post-surgery, and has been maintained on small doses of calcium carbonate and 1- $\alpha$ cholecalciferol so controlling the serum calcium within the normal range, the PTH remaining at undetectable levels.

\section{Discussion}

Reports of the development of carcinoma in association with benign disease have been sporadic. There have been reports of carcinoma associated with multiple endocrine adenomatosis (MEA 1), either all or some of the remaining glands showing hyperplasia (Dinnen et al., 1977; Mallette et al., 1974). Other reports have shown carcinoma with one or two of the other glands being hyperplastic (Murayama et al., 1977; Golden et al., 1965), although Schantz \& Castleman (1973) in an extensive review of 70 cases found no association.

The significance of the reported case is that there is conclusive evidence of long standing benign parathyroid disease, i.e. secondary hyperparathyroidism, 


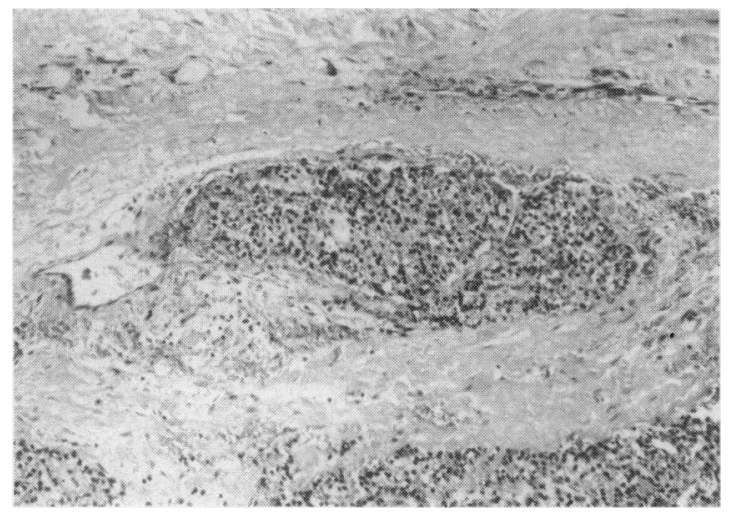

Figure 1 Capsular region of the parathyroid carcinoma, showing a small vein invaded by the tumour. ( $\mathrm{H} \& \mathrm{E}$ $\times 125)$.

when all glands would be hyperplastic, before the matignant transformation.

The histological diagnosis of parathyroid carcinoma is difficult, a variety of features often being present. The diagnostic histological criteria have been described by Schantz \& Castleman (1973) and Castleman \& Roth (1978). The essential characteristics are the presence of mitotic figures within parenchymal cells, vascular and local tissue infiltration; capsular invasion and a trabecular structure are regarded as being of less diagnostic importance, as these features can be seen in adenomata.

Carcinoma of the parathyroid is a rare neoplasm,

\section{References}

CASTLEMAN, B. \& ROTH, S.I. (1978). Tumours of the parathyroid glands In: 2nd Series; Fascicle 14; Atlas of tumour pathology, p. 74-82 Armed Forces Institute of Pathology; Washington, U.S.A.

DINNEN, J.S., GREENWOOD, R.H., JONES, J.H., WALKER, D.A. \& WILLIAMS, E.D. (1977). Parathyroid carcinoma in familial hyperparathyroidism. Journal of Clinical Pathology. 30, 966.

GOLDEN, A., CANARY, J.J. \& KERWIN, D.M. (1965). Concurrence of hyperplasia and neoplasia of parathyroid glands. American Journal of Medicine, 38, 562.

HOLMES, E.C., MORTON, D.L. \& KETCHAM, A.S. (1969). Parathyroid carcinoma: a collective review. Annals of Surgery, 169, 631. the reported incidence ranging from $0.6 \%$ to $4 \%$ (Schantz \& Castleman 1973; Van Heerden et al., 1979). Characteristically it is slow growing, but with intense endocrine properties, being both locally invasive and metastasising. Van Heerden et al. (1979) noted that compared to adenomata, all carcinoma were large, $50 \%$ in his series presenting with a palpable mass, and had higher serum calcium and PTH levels. Furthermore, $25 \%$ present with metastasis, usually in the regional lymph nodes.

The management of both the local and endocrine effects is surgical, radiation and chemotherapy being ineffective (Van Heerden et al., 1979; Holmes et al., 1969). At operation, it is imperative not to burst the capsule as the tumour implants readily into the wound, leading to early recurrence (Holmes et al., 1969). Post-operatively the serum calcium should be kept near to the upper limit of the normal range, to reduce PTH stimulation to a minimum. Early surgery is the only effective treatment for these patients, $30 \%$ of whom can expect to get a local recurrence, and $30 \%$ of whom will die of the disease within 5 years (Schantz \& Castleman, 1973).

The possibility of malignant transformation in benign parathyroid disease, albeit a rare event, should be considered in autonomous hyperparathyroidism, especially in the presence of a high serum calcium and PTH, or if associated with a large gland and wheB surgical dissection proves difficult.

With the increasing number of dialysis patients, 透 would appear to indicate that the treatment of even borderline tertiary hyperparathyroidism should not be delayed unduly.

MALLETTE, L.E., BILEZIKIAN, J.P., KETCHAM, A.S. \& AURBACH, G.D. (1974). Parathyroid carcinoma in familial hyperparathyroidism. American Journal of Medicine. 57, 642.

MURAYAMA, T., KAWABE, K. \& TAGAMI, M. (1977). A case of parathyroid carcinoma concurred with hyperplasia: an electron microscopic study. Journal of Urology, 118, 126.

SCHANTZ, A. \& CASTLEMAN, B. (1973). Parathyroid carcinoma; a study of 70 cases. Cancer. 31, 600.

VAN HEERDEN, J.A., WEILAND, L.H., REMINE, W.H., WALLS, J.T. \& PURNELL, D.C. (1979). Cancer of the parathyroid glands. Archives of Surgery. 114, 475. 